\title{
JACOBSON'S CELEBRATION OF COMEDY IN KALOOKI NIGHTS
}

\section{LA CELEBRACIÓN DE LA COMEDIA EN KALOOKI NIGHTS, DE JACOBSON}

\author{
AÍDA DÍAZ BILD \\ Universidad de La Laguna \\ adbild@ull.es
}

\section{Abstract}

Most scholars agree that Jewish humour is a relatively modern phenomenon born out of the unique Jewish experience of exile, segregation and persecution. Howard Jacobson is a British Jewish writer who has always praised comedy and paid special attention to Jewish comic sensibility. He has emphasised the coping and liberating function that humour has exercised for the Jews, allowing them to transcend the terrible circumstances of their lives. Jacobson does not believe that humour removes pain, but that it contributes an emotional factor that makes the pain more bearable by affirming and celebrating life. He is convinced that there is something particularly Jewish about the way in which he fuses comedy and tragedy in his novels, since Jews have always joked in the face of affliction. Jacobson also stresses how from the very beginning the novel has been defined by its subversive and God-defying character. After explaining Jacobson's main ideas on comedy and how they are shared by scholars who have examined the characteristic features of Jewish humour, I will analyse how they are reproduced by the narrator in Kalooki Nights (2006).

Keywords: Howard Jacobson, Jewish humour, comedy, transcendence, subversion. 


\section{Resumen}

La mayor parte de los críticos coinciden en que el humor judío es un fenómeno relativamente moderno, fruto de la experiencia única de exilio, segregación y persecución vivida por los judíos. Howard Jacobson es un escritor judiobritánico que siempre ha elogiado la comedia y ha prestado especial atención a la sensibilidad cómica judía. Ha enfatizado la función liberadora que el humor desempeña para los judíos, permitiéndoles transcender las terribles circunstancias de sus vidas. Jacobson no cree que el humor elimine el dolor, pero lo hace más soportable al reivindicar y celebrar la vida. Está convencido de que hay algo particularmente judío en el modo de combinar la comedia y la tragedia en las novelas judías, porque los judíos siempre han bromeado ante el infortunio. Jacobson también subraya que desde el principio la novela se ha definido por su carácter subversivo y desafiante. Después de explicar las principales ideas de Jacobson sobre la comedia y en qué medida las comparten otros estudiosos del humor judío, en este artículo se analiza cómo las reproduce el narrador de Kalooki Nights (2006).

Palabras clave: Howard Jacobson, humor judío, comedia, transcendencia, subversión.

\section{Introduction}

In 1893 Hermann Adler, the Chief Rabbi of the United Hebrew Congregation of the British Empire, delivered a lecture in which he defended the Jews from those denying them the faculty of laughter and the power of evoking laughter:

With the Hebrews, however, it is otherwise. They, at a comparatively early stage in their history, attained that ripe and strong mental development which the elaboration of wit and the comprehension of humour demand. And there is one leading trait in the annals of the Hebrew race which engendered and stimulated to the highest degree their vis comica - the faculty of saying witty and humorous things. (1893: 457)

Little did Adler suspect when he said those words that the situation was going to change drastically in the following years. Thus in 1943 Kohn and Davidsohn already took for granted the existence of a distinctively Jewish sensibility:

The wit and humor of the Jews are age-old and were present at all times, so that the gift of glossing over in humorous manner and of ironizing about the various forms and expressions of being or of recognizing their comical side may be forthwith asserted to be an essential characteristic of the Jews. Jewish wit and humor have fructified the literature of all people. (1943: 545) 
This characterization of the Jews as peculiarly humorous people has been endorsed by both Jewish and non-Jewish scholars. Thus, for instance, Ziv has explained that "[f]rom the end of the last century, Jewish humor became widely recognized as superlative humor and is growing in renown to this very day" (1986: 48), whereas Landmann has claimed that "[e]xperts in Jewish humour are in fact agreed that it is more acute, more profound, and richer in expression than that of any other people" (1962: 194). Most of the critics who have explored the image of the Jews as 'the People of the Joke' have tried to define what makes Jewish humour such a unique phenomenon. Oring, who like most scholars believes that Jewish humour is a relatively modern phenomenon originating in the nineteenth century in Eastern Europe, has given us one of the best descriptions of Jewish humour:

The conception of a Jewish humor derives from a conceptualization of Jewish history as a history of suffering, rejection, and despair. Given this history, the Jews should have nothing to laugh about at all. That they do laugh and jest can only signal the existence of a special relationship between the Jews and humor and suggests that the humor of the Jews must in some way be distinctive from other humors which are not born of despair. (1983: 266-267)

The main aim of this essay is precisely to analyse the way in which Howard Jacobson, a British Jewish writer, has celebrated comedy and explored the image of the Jews as the People of the Joke and how his main ideas are reproduced by the narrator in Kalooki Nights (2006). Throughout the essay I will show that his tenets are shared by scholars who have examined the characteristic features of Jewish humour.

\section{Howard Jacobson on Comedy}

Jacobson is a British Jewish writer who is proud of being labelled a Jewish writer and does not hesitate to describe himself as "entirely and completely Jewish" (in Jacobs 2008). In fact, most reviewers and critics have pointed out that few Jewish British authors have written so explicitly and overtly about Jewish experience and identity. Like most critics (Cheyette 2003; Gilbert 2013; Weber 2007), Jacobson believes that although there seems to be "a new, unapologetic and unashamed generation, less worried about what will happen if the British notice there are Jews living here" (in Schischa 2011), British Jews do not have the cultural influence Jews have in America. Jacobson thinks that it is time Anglo-Jewish writers should be less embarrassed about what it means to be British Jews. For him the story of Jewish assimilation into British life and culture in order to avoid being accused of introversion and parochialism is one of failure since British Jews have been incapable of addressing directly the challenge of being Jewish, which should have 
been "the raison d'être for their art" (Jacobson 2006: 45). He insists that instead of seeing America as the model to be imitated, British Jewish writers should delight in the here and now and engage creatively with it: "We have been in this country a while now. The story of our finely tuned accommodations to English culture is a fascinating one, sometimes tragic, often heroic, always funny, and never less than urgent beneath a quiescent surface. It is time we told it. We should be more interested in ourselves as English Jews. ENGLISH... JEWS” (2006: 46).

Howard Jacobson has long been recognized as a great comic novelist. Again and again in articles and interviews Jacobson has argued that humour plays a very important role in life and literature. Interestingly enough, he admits that his constant celebration of comedy is closely linked to the fact that he is a Jewish author writing explicitly about the experience of Jews in Britain: "I think a Jew knows that very funny is very serious. It's part of my errand, something I feel I have to propagandize" (in Manus 2004). Jacobson claims that comic fiction should be taken seriously and denounces the false division between comedy and seriousness that has been created:

But there is a fear of comedy in the novel today — when did you last see the word "funny" on the jacket of a serious novel? - that no one who loves the form should contemplate with pleasure. [...] But we have created a false division between laughter and thought, between comedy and seriousness, between the exhilaration that the great novels offer when they are at their funniest, and whatever else it is we now think we want from literature. (2010b)

For Jacobson the term 'comic novelist' is as redundant as the term 'literary novelist': "The novel was born of restless critical intelligence, and it was born laughing" (2010b). Jacobson stresses how from the beginning the novel has been defined by its subversive character: "Comedy breaks every trance- that's its trance. Comedy is nothing if not critical" (2010b). Jacobson goes so far as to say that it is precisely because the novel is scornful, spiteful, that it should be described as "sacred" (in Irvine 2010). In its God-defying and subversive character the novel resembles the satyr play which was performed after the tragic trilogy and which developed the same narrative and mythological motifs as had the trilogy that preceded it, but showed a different perspective: "This is not to say that the Greeks value comedy higher than tragedy, but they were in no doubt which was the better note to end on. Comedy affirmed the vigorous and unpredictable liveability of life" (Jacobson 2010b).

Jacobson thinks that the novel has been the expression of freedom, as the work of Rabelais or Cervantes patently shows. By challenging the reader's beliefs and sympathies comedy affirms and celebrates life: “[...] comedy spares nothing and spares no one. And in the process asserts the stubbornness of life. Why would we 
want to read anything less" (2010b). Jacobson points out that the novel does not exist to make us feel good or, as he puts it, “[n]o good writer ever merely cheered us up" (2012). Nevertheless, at the end of the novel our hope is rekindled: "How not feeling good nonetheless conduces to our not feeling bad, indeed conduces to our feeling exhilarated, is one of the great mysteries of art” (2010b).

Jacobson rejects the notion that comedy comes after tragedy or that tragedy is more profound than comedy: "Maybe, but any fool can make you cry. If I want to see what a writer's made of, I say, go on, make me laugh then!" (in Pearson 2003). $\mathrm{He}$ is irritated by the lack of respect for comedy (Irvine 2010) and feels "desperate" to defend comedy because he does not like novels if they are not funny (in Tracy 2011). Jacobson has argued that not only is the comic novel underrated, but that "they will not forgive you for being funny" (in Pearson 2003). Because he firmly believes that comedy can deal with the most tragic themes and circumstances without trivializing them, he insists that a comic writer is as serious as a tragic one: "But I can say I am as serious as anybody else. I am serious in my intentions as anybody" (in "The Plot against England" 2010). In fact, it has been pointed out that Jacobson is too serious for his own good (Cheyette 1999) and that a novel by Jacobson is almost "a comedy about tragedy" (Boylan 2011). This explains why Jacobson has rejected the comparison with Philip Roth. He admires his work, but he regrets that he has stopped being funny:

He is perfectly within his rights to have stopped being funny, but I feel: "Now more than ever I want you to be funny... now that you are in the toils and at any moment you're going to die and you are fed up with everything and everybody". I feel the same with Woody Allen: "Fine, it was easy before. Joke now". It's never too serious to laugh. (in Jacobs 2008)

He prefers to call himself the Jewish Jane Austen not only because he considers himself "an English novelist working absolutely square in the English tradition" (in "The Plot against England" 2010), but because comedy was central to Austen's themes, however tragic or profound: "Comedy is a very important part of what I do. I sometimes say I'm a Jewish Jane Austen” (in Manus 2004). Gilbert absolutely agrees with Jacobson's description of himself as an author because she believes that he has rewritten "the English novel of manners, turning it instead into a particularly British-Jewish comedy of bad manners” (2013: 107).

When Jacobson was awarded the Booker Prize for The Finkler Question (Jacobson 2010a), Andrew Motion, the Booker chairman, said that Jacobson "certainly knows something that Shakespeare knew - that the tragic and the funny are intimately linked" (in Jeffries 2010). The main reason why Jacobson fuses comedy and tragedy in his novels is because he firmly believes that humour allows us to transcend life's miseries: "Comedy is a human invention to deal with the sadness 
of life. It's our greatest achievement. Forget the pyramids. Comedy" (in Tracy 2011 , emphasis in original). Jacobson does not think that comedy removes pain or suffering, but makes these experiences more bearable by affirming and celebrating life:

There is no being reconciled to loss. What's gone is gone. What's suffered is suffered. But some novelists make it possible for us to stare at pain with bitter and derisive comedy, and because there is a part of us that values truth above illusion, we grab at that bitter comedy for dear life. (Jacobson 2012)

He insists again and again on the same idea: "Comedy is the handmaiden of tragedy', he said, adding that 'humor doesn't make things light - quite the contrary'. It makes the tragedy of life bearable; 'We affirm life with it'" (in Herschthal 2010). Interestingly enough, like many critics, Jacobson believes that there is something particularly Jewish about mixing tragedy and comedy: "tragedy and comedy at once; how we do it... When I do comedy... it bleeds" (in Herschthal 2010). Jacobson claims that the more tragic the themes the more obliged he feels to exploit the comedy in them: "Jewish themes, in particular, are susceptible to comedy of the most stringent sort. It's what Jews have always done in the face of affliction- joked. Not to make light of catastrophe, but to bring every resource of intelligence to bear on it, to understand it fully, and to affirm the energy of life in the face of horror. Laughter might, in the end, be the only cure for the poisoned heart of memory" (in Mullan 2010). In fact, Tracy establishes a very interesting comparison between the interviewer and writer Paul Holdengräber and Jacobson as representatives of the two archetypes of the Jewish intellectual. Whereas Holdengräber incarnates "the staid German Jew, even-keeled, cerebral, always a step removed from the messiness and flesh and thingness of day-to-day life", Jacobson is "the ribald and morbid Jew from the Pale - that goofy mane of hair, those capital-b Bushy eyebrows, and that gigantic nose! - the fragility of whose life has led him to fear harm and to raise humour as a shield" (Tracy 2011).

This notion of Jewish humour as essentially transcendent in the sense that it allows Jewish people to cope with their suffering and liberates them from the social, political and economic forces that oppress them is shared by many scholars. Thus Saper has pointed out that the comic vision of life has allowed the Jews of America, like the Jews of the Diaspora in general, to cope with the tragic nature of their lives, maintain their dignity, equilibrium and sanity, and look to the future: "At the risk of redundancy, it should be emphasized again that there is a unique tendency - cultural, religious, and ethnic - for the Jew to pick up on the terrible miseries of his/her life as well as its absurdities, to make jokes and laugh at them" (1991: 54). Ziv also believes that Jews have always used humour as a psychological defence mechanism to distort their tragic and threatening reality and make it laughable by seeing the absurd in it: 
Laughing at the absurdity of reality as well as at themselves is an old tradition with Jews. Being the chosen people and living in the worst possible conditions, victims of pogroms and targets of hatred from their fellow human beings, seemed some kind of divine irony. One way of dealing with it was to adopt irony and use it to deal with reality. (1988: 114)

Jews refuse to let their harsh living conditions crush their spirit: "Despite the tragedies that befell them, the Jews nurtured an optimistic element of hope in the redemption that would come in the wake of their suffering" (Ziv 1986: 54).

Berger (1997) also argues that the Jewish comic sensibility that originated in the Yiddish culture of Eastern Europe is defined by the element of tragicomedy. The Jews of Eastern Europe, and especially those living in appalling circumstances in Russia, were aware of the incongruity between the promises of a majestic destiny for Jewish people and the miserable conditions in which they lived. They developed a tragicomic approach to life in order to cope with their painful predicament. Tragicomedy allowed Jewish people to provoke laughter through tears. ${ }^{l}$ In fact, Berger affirms that Jewish humour is "a sign of the invincible survival power of the Jewish people that - even as Nazi barbarism had destroyed most of Jewish culture in Europe - it found new incarnations in America and Israel” (1997: 88).

Cohen agrees with Berger that Jewish humour was born out of the awareness of the contradictions between the heavenly promise of being the "chosen people" and their cruel reality and emphasises that Jewish comedy is defined by a peculiar mixture of laughter and trembling which has allowed Jews to survive in a hostile world: "By laughing at their dire circumstances, Jews have been able to liberate themselves from them. Their humor has been a balance to counter external adversity and internal sadness" (1987: 4). Robert Alter not only underlines the mixture of comedy and tragedy that defines Jewish humour, but points to the courage needed to laugh in the face of suffering and despair:

If disaster, whatever the scale, seems to be our general fate, the persistence of the comic reflex is itself evidence of the perdurability of the stuff of humanity: a shrug is a small and subtle gesture, but, in the face of the harshest history, it may take a world of strength to make. (1987: 36)

Jacobson not only agrees with these critics that here is something particularly Jewish about this mixture of tragedy and comedy, but firmly believes that the ingenious, joking Jew is the Jew in essence: “over hundreds if not thousands of years of exile the Jew had grown emotionally bent instead of straight, contradictory instead of unified, and the clearest manifestation of this bentness was the highly wrought comedy with which he viewed his condition" (2001: 7). Jacobson rejects the notion put forward by many scholars that by laughing at their own ambiguities Jews are betraying self-hatred: ${ }^{2}$ 
But I ask you which is the self-hating Jew - the Jew who makes a permanent witticism of the imperfect, not to say contradictory, life he leads, or the Jew who winces at such satire, recoiling from an ancient Jewish recourse, and therefore from an important ancient aspect of Jewish genius? (2001: 7)

Jacobson criticizes Jewish intellectuals who try to hide their Jewishness and therefore their contradictions:

And if I complain that it isn't strictly Jewish to grow up straight and tall and jokeless, am I not perpetrating that version of Jewishness which every enlightened Jew since Moses Mendelssohn and every Zionist since Herzl has been trying to ditch?

Yes, I am. For the simple reason that that's the Jewishness I like and admire and value and see the point of, and see a future for, most. (2001: 8, emphasis in original)

It is relevant to point out that Jacobson's insistence on the lack of self-hatred in Jewish humour is shared by many scholars who have emphasised that the selfmocking jokes that the Jews are given to making have allowed them to cope with the tragic nature of their lives (Davies 1991; Saper 1991; Ziv 1986).

\section{Max Glickman: Jacobson's Voice in Kalooki Nights}

Gilbert has claimed that although most contemporary British Jewish writers tend to ground their narratives in specific British locations, exploring the particular experiences of British Jews in the here and now, some are also exploring the Holocaust in challenging ways: "Like Jacobson in Kalooki Nights, they ask difficult and provocative questions about their own generation's relationship to history" (2008: 403). Jacobson has admitted that with Kalooki Nights he had decided

to go where you're not supposed to go, not as a measure of disrespect, but the very opposite [...] That's the great test, if you're going to be a great comic writer, not a humorist, you've got to take it into the throat of grief. Can you make laughter and seriousness so close that they are the same thing? There's nothing more wonderful than when the comedy's got horror in it, got blood in it. (in Irvine 2010)

Jacobson proves in Kalooki Nights that it is possible to write about the Shoah in a comic way without trivializing its horrors. In fact, he has explained that his aim in the novel was not to recreate history but to find a different discourse with which to talk about the Holocaust: "Comedy is one way to change the discourse. I believe in taking up the challenge of Hamlet in that wonderful scene, holding the skull of Yorick and confronting him: 'You were a jester"' (in Jacobs 2008). In order to achieve his aim Jacobson has chosen the "perfect" narrator: Max Glickman, a cartoonist obsessed with the Holocaust whose "masterpiece", Five 
Thousand Years of Bitterness, is a comic history of the crimes committed against the Jewish people. Because Max is a self-conscious artist who constantly draws attention to his own compositional procedures, Kalooki Nights embodies dimensions of self-reflexivity that allow Jacobson to "explore a theory of fiction through the practice of writing fiction" (Waugh 1993: 2, emphasis in original). Metafiction in Kalooki Nights lays bare certain literary conventions and in doing so makes the reader revise their ideas about the nature of fictional narrative. Jacobson achieves his goal by making Max, who has spent most of his life drawing caricatures of the enemies of the Jews, echo his own ideas on comedy. ${ }^{3}$ Thus, like his creator, Max repeatedly emphasises the subversive character of humour: "A cartoonist, you see, not a landscape painter or gardener or cartographer. Agitation, satire, distortion, not the beauty of the visible world humming exquisitely on its axis" (Jacobson 2007: 88). He warns the reader not to expect respect from a cartoonist: "But a cartoonist isn't there to help. Not in the conventional sense, at any rate. A cartoonist is there to make the complacent quake and the uncomfortable more uncomfortable still" (23). He confesses to the reader that he really does not know why he draws satirically when by nature he is melancholy and withdrawn: "Why - speaking of disloyalties, forsakings and acts that seemingly cannot be explaineddid I forsake myself to draw cartoons, when I am averse by nature to caricature, ribaldry and violence?" (11, emphasis in original). Max asserts that for the comic mode nothing is sacred, everything can and should be criticized. As he says to his rather peculiar Orthodox friend Manny when the latter accuses him of embracing ugliness as an artist:

How can I not be in an argument with beauty? I'm a cartoonist. More to the point, I'm a Jewish cartoonist. As an Orthodox Jew yourself, or as a one-time Orthodox Jew -I don't presume to know what you are now - you should approve of this. Leviticus 26, Manny, "Ye shall make you no idols nor graven image". I happen to take that prohibition very seriously. Not in its sensuous applications but in its ethical ones. It is not good to lose oneself in art. It is idolatrous. Lose yourself in art and you end up not knowing where you begin and end. It is a mistake to fuse with the image. Well, you can't fuse with mine, Manny. It won't let you. It won't allow it. If by ugliness you mean the ceaseless mockery, through a visual medium, of all the seductions of visual media, then yes, OK, have it your way, my drawings are ugly. (264)

Max believes that only laughter or mockery save you from idolizing images, from worshipping idols. That is why as a cartoonist he could not "resist comic gods and goddesses who mocked the spiritual" (Jacobson 2007: 281). Mendel, a camp prisoner who fulfils the role of Max's alter ego in the novel, goes so far as to say that because the caricaturist demystifies reality he is a kind of god: "But because the caricaturist is by nature a satirist, and the impulse to satire is denial, he is also the most godlike. In his act of creation, the satirist destroys" (358-359, emphasis 
in original). Mendel, who makes this statement during a conversation with Ilse Koch, the "Witch of Buchenwald", believes, like Jacobson, that satire is written into Jewish nature:

She $i$ getting better. She reads what he is thinking. "Is it Jewish, this satire of yours, Jew?"

"It is, Frau Koch. Satire is written into our natures. Nietzsche believed we invented democracy out of a satiric impulse, as a refusal of aristocrats and heroes".

She doesn't, of course, know who Nietzsche is. The education of the German people, though advanced, is a long way from being complete.

"So are all Jews satiric?"

"Only the clever ones, Frau Koch".

"I thought you were all clever".

"We are, Frau Koch".

She strikes his face again, with her gloved hand. "Don't be satiric with me, Jew. I have told you I will remove all satire from your mind. You have said satire is written into your natures. So if I remove the satire from the Jews, there are no Jews, nicht wahr?"

Ja wohl, Mendel thinks. (360-361, emphasis in original)

This quotation is comic not only because it explores one of the most common stereotypes of Jews - their pride and preoccupation with cleverness - but because it exploits what Berger considers to be one of the distinctive characteristics of Jewish humour: the use of a question and answer format which has its origin in the dialectical manner of debating the Talmud (1997: 92-93). In fact, Jacobson, who considers that to be Jewish is "to demur" (2001: 5), has described Jewish writing in the very same terms:

A strong, disputatious voice. You feel you're listening to ethical argumentativeness that reminds you of the Talmudic pedantic disputatiousness. Jews love the meaning of language. They're seeking clarity, seeking to make a law, make a distinction between a law and how does this thing differ from that thing. For a Jew, language is always at the service of intelligence. (in Manus 2004)

This dialectical reasoning which has defined Jewish thinking since the very beginning is, according to Jacobson, the cornerstone of the Jewish joke: "an oversubtle acknowledgement of our own over-subtlety" (2001: 6).

Max's irreverence sometimes gets him into trouble and makes editors reluctant to publish his work as happened with

a series of irritably lewd cartoons I once drew, a sort of Rake's Progress set in Stamford Hill, where every strumpet was a Jewess in a sheitel, but which no reputable publication was prepared to take, not even Playboy, despite my offering to redraw the location to make it look like Crown Heights. (Jacobson 2007: 254) 
Obscenity is present in most of the cartoons produced by Max and, as Sicher and Weinhouse have explained, by creating a cartoonist who specializes in obscenity Jacobson is "breaking a taboo on things Jews don't do" (2012: 207), since Jewish humour contains almost no scatology and remarkably little sexuality. Sexual humour is even rarer in Israeli culture: "Sexual cartoons are extremely rare and almost never obscene. Jewish humor, even before the new state of Israel, was never sex-minded" (Ziv 1988: 130).

Where Max proves to be more subversive is precisely in his treatment of the atrocities committed against the Jewish people. He can find no publisher for Five Thousand Years of Bitterness because he has broken the sacred rule that says that it is inappropriate to deal with serious issues in a comic mode: "Well, what else should I have expected? Adorno famously said that, after the Holocaust, poetry wasn't a good idea. He never thought there was need to include cartoons in that proscription" (Jacobson 2007: 168). Max is referring here to Theodor Adorno's famous dictum: "To write poetry after Auschwitz is barbaric" (1955: 34). This statement generated a great debate about whether the Holocaust is capable of representation. On the one hand there are those who are sceptical about there being an appropriate discourse to evoke the Holocaust. Thus Steiner claims that " $[\mathrm{t}]$ he world of Auschwitz lies outside speech as it lies outside reason. To speak of the unspeakable is to risk the survivance of language as creator and bearer of humane, rational truth" (1985: 146), ${ }^{4}$ while Howe affirms that the literary imagination is incapable of rendering intelligible the extermination of $6,000,000$ Jews: "what can the literary imagination, traditionally so proud of its self-generating capacities, add to - how can it go beyond - the intolerable matter cast up by memory?" (1988: 187). The novelist tries to make sense of the Holocaust, but he cannot because he lacks a structuring set of ethical premises and therefore the aesthetic biases which would allow him to integrate his materials.

There are other critics who not only believe that the literary imagination can represent the Holocaust, but argue that comedy can treat the Holocaust respectfully while at the same time offering a different perspective. In "Holocaust Laughter?" Des Pres affirms that it is possible for fiction to represent the Shoah and argues that the use of the comic mode to write about the Holocaust helps both reader and writer to transcend the horrors of the event. Des Pres knows that by formulating this thesis he is challenging one of the sets of fictions that shapes Holocaust discourse: "The Holocaust shall be approached as a solemn or even sacred event, with a seriousness admitting no response that might obscure its enormity or dishonour its dead" (1991: 217). Tadeusz Borowski's This Way for the Gas, Ladies and Gentlemen, Leslie Epstein's King of the Jews, and Art Spiegelman's Maus are works that refuse to take the Holocaust on its own crushing terms: "[...] pity and 
terror are held at a distance, and this is not, finally, a bad thing. To be mired still deeper in angst and lament is hardly what is needed. The value of the comic approach is that by setting things at a distance it permits a tougher, more active response" (Des Pres 1991: 232). ${ }^{5}$ A similar idea is expressed by Cory: "As a literary device it [humour] has lent credibility to witness literature and functioned aesthetically to make the unfathomable accessible to the minds and emotions of the reading public" (1995: 39).

Other critics have concentrated on the use of comedy in the cinema to represent the Shoah and their conclusions are very similar to those of Des Pres and Cory. One of the most interesting texts is "Art, Morality, and the Holocaust: The Aesthetic Riddle of Benigni's Life Is Beautiful", in which Haskins analyses Benigni's film and argues that Benigni has not defiled the Holocaust by telling a comic story:

And whatever else one may think about Benigni, he well understands, as does this film as a whole, that there are no subjects, not even the Holocaust, that an otherwise mature adult cannot, under the right conditions, find funny, and some subjects, including the Holocaust, that many of us, for better or worse, need to find funny. (2001: 380)

Haskins believes that there is no clear criterion to assess the truth claims of Holocaust representation, because there are so many different ways in which the Holocaust can be imagined. In fact, Viano reflects the very same idea in his article on Benigni's film when he asserts that Life Is Beautiful demonstrates that comedy can treat the Holocaust respectfully while at the same time offering a different perspective: "It should be noted here that Benigni's project, far from cheapening it, confirms the Holocaust as history's worst nightmare and reinscribes it in the collective memory through an unusual code" (1999: 29).

Des Pres insists that "[c] reative writers, moreover, are quicker to break taboos than critics like ourselves" (1991: 232-233), which is precisely what Jacobson is doing in Kalooki Nights. Manny says that it is the use of cartoons, the use of comedy, that makes Five Thousand Years of Bitterness "blasphemous" (Jacobson 2007: 39). Max knows that he is right, that it is very difficult to overcome the prejudices against using comedy to deal with profound and painful themes:

I made a cartoon of it once. Two old Jews arguing. One with a bubble coming out of his mouth declaring "Never again", the other with his fists in the air and an answering bubble, "If I have to hear you saying never again ever again". But I was unable to place it. I gave it away in the end to the plastic surgeon who wouldn't touch my nose. Hard to get people to laugh at the Holocaust. (119)

Like Jacobson, Max believes that the comic writer is as serious in his intentions as anybody: "For a cartoonist I am serious to a fault" (Jacobson 2007: 264). 
But he also knows that for many critics and writers comedy is just a trivial form, which explains why Isaiah Berlin and other well-connected Jews never responded when they were sent a copy of Five Thousand Years of Bitterness: "Mine was not, that was all I could deduce - since not every one of them had come to hear of me first as a dick-artist - their idea of serious discourse on a Jewish theme" (258). Better than anyone else Max understands the frustration that beset Bernie Krigstein, who gave up illustrating comic books and returned to painting: "[...] he'd grown to be desperately unhappy in what he did, and considered himself to be a serious artist who had squandered his genius on a trivial form" (239). Max admits that the problem with Krigstein "was that he didn't have much of a sense of fun" (421) and points out that his comic-book story "Master Race", which tells the story of the commandant of a Nazi camp who escapes before the Russians arrive but is recognized by one of his victims years later, was a great success precisely because it was not comic, because it obeyed the rule that says that the Holocaust can only be approached in a serious and solemn way.

Max has been hired to write the story of his Orthodox friend Manny Washinsky, who murdered his parents by gassing them in their beds as they slept. Max knows that Manny wonders whether he is fit "as a man of comedy and exaggeration, to interpret his story" (Jacobson 2007: 267), but for Max there are only two sorts of Jews: "I mean Jews who see the funny side of things and those who don't" (421). Jewish authors like Krigstein or Mark Rothko belong to the second group, whereas Max is obviously a good representative of the first one: "but for me nothing was so dreadful that I couldn't see its essential drollery" (422). Jacobson believes that what Jews do best is make jokes — "No one makes jokes like Jews" (in "The Plot against England" 2010) - and Max argues that jokes play an important role in Jews' lives: “Jew, Jew, Jew. Joke, joke, joke. Why, why, why?" (Jacobson 2007: 8). Max knows that laughter has allowed Jewish people to transcend disappointment and suffering: "I was the fruit of Five Thousand Years of Bitterness which meant that I was heir to Five Thousand Years of Jokes" (47). Humour does not obviate sadness or eradicate pain, but makes these emotions more bearable. Thus, referring to Thurber, Max says: "What made Thurber humorous was desperation. Only I don't think the word for it is humor exactly. It's not humor when you're at the end of a rope. What makes Thurber funny is that you smell death in every sentence he wrote and despair in every line he drew" (57). In the same way that Max's atheist father and his orthodox uncle have ferocious arguments about Hitler and the extermination of the Jews "as a sort of magic, to ward off evil" (4), Max uses humour to help Jewish people bear their misfortunes: "[...] that too is what I'm paid for- excoriating my people when I'm not shielding them from harm" (95). Like his creator, Max believes in the survival value of laughter and this is why he is 
sorry that his father has not understood the real meaning of the sexual fantasies portrayed in Five Thousand Years of Bitterness: "I wanted to protest that he hadn't taken adequate cognisance of their hard-ons/hards-on; that their hard-ons/hardson, artistically speaking, stood for the virility of the Jewish people in the face of adversity" (205). It is highly revealing that when Max's uncle refers to Ilse Koch, one of the female Nazi torturers who was said to have made lampshades out of Jews' skin, Max feels that it is his duty to emphasise how ludicrous his mother's attempt to cope with this reality sounded: "'Oh, is she the one who made the lampshades?' my mother asked. It's the obvious joke, but she made it sound like an interior design query. And even if she hadn't, it's my obligation as a cartoonist to make out that she had" (118).

As we saw above, Jacobson believes that there is something particularly Jewish about the tendency to combine tragedy and comedy and has Max quote from Wittgenstein to prove his theory:

You get tragedy where the tree, instead of bending, breaks. Tragedy is something un-Jewish.

Ludwig Wittgenstein (Jacobson 2007: 121)

In fact Jacobson has acknowledged that he feels that he has a Jewish mind: "What a Jew is has been made by the experience of 5,000 years, that's what shapes the Jewish sense of humor, that's what shaped Jewish pugnacity or tenaciousness" (in Manus: 2004). ${ }^{6}$ Jacobson has repeatedly reinforced his sense of Jewishness: "What if our genius is our history, what if the distortions of the shtetl and the ghetto and the margins are our nature now? I doubt that Israel is going to make a new Jew of us" (2001: 12).

Max also criticises those who believe that by laughing at their own contradictions Jews are betraying self-hatred and therefore would like to take "the bitter selfreflexive comedy out of the Jew" (Jacobson 2004). Like his creator, Max does not think that by removing all references to Jewishness a Jew is showing any kind of self-love (Jacobson 2001: 7). Jacobson's explicit criticism of those Jews who try to ignore their own ambiguities and peculiarities becomes clear in the following conversation when Errol Tobias accuses his friend Max of drawing cartoons that show little respect for Jews:

"Well, why's that funny, Max? What's amusing about Jews always seeing themselves as being shat on? Isn't it time we outgrew that?"

"Ah, so it's not my shitting on those poor old Jews that bothers you, it's my doing it for the entertainment of the Christians. The accusation is not Masochismus but Nestbeschmutzing. Well, as far as charging me with nestbeschmutzing is concerned, let me tell you that others have got there before you. There isn't a Jew living who isn't 
guilty, in the opinion of some other Jew, of fouling the nest. Unless you take a vow of silence or wire your jaw you're a nestbechmutzer. And if you do take a vow of silence or wire your jaw you're suffering from Judische Selbsthass. We either love ourselves too much or hate ourselves too much. To a Jew there is no acceptable way of being Jewish [...]" (Jacobson 2007: 344)

In fact, Max argues that Five Thousand Years of Bitterness was a failure not only because it used the comic mode to evoke a history of suffering, but because it was published at a time when Jews did not want to be reminded of their painful past but celebrate their glorious present:

I like to think the timing was unfortunate. Winter 1976 was when Five Thousand Years of Bitterness saw the light of day here and in America, the warm pro-Yiddler glow of the Entebbe Raid not yet faded. If you were Jewish you were proud again, just as you had been after the Six Day War in 1967, no longer finding your reflection in the furrowed brows of rabbis and philosophers, but in fighter pilots and one-eyed generals. So the last thing you wanted to be reminded of was five thousand years of loss and jeering. Jeer at a Jew post-1967 and you risked a strafing from the Israeli Air Force. Now, post-Entebbe, anyone stealing a Jew could expect to wake to see commandos in his garden. We took no shit. And people who take no shit don't have to go round making jokes about themselves. Jokes are the refuge of the Untermenschen. Hadn't that been one of the declared aims of Zionism - the creation of a people who would no longer value themselves only for the wit they brought to bear on their misfortunes? A people, maybe, who would never have to make a joke again. Least of all against themselves. [...] We're a country, we're a nation again. We don't do funny and we don't do fucked. (Jacobson 2007: 167)

Max reinforces the same idea when he tells Manny that "Israel's different. You don't laugh in Israel" (Jacobson 2007: 421). It is true that critics such as Landmann (1962) believe that with the rise of the Jewish state, humour as a weapon or a means of transcendence became obsolete, since they were not victims any longer. But what Jacobson is doing here is making fun of people like Chaim Weizmann who, as Jacobson argues, saw in Zionism the opportunity to make Jewish humour disappear: "Israel itself, in other words, came into being, as an idea, to put paid to that 'permanent witticism' which is the Cain's mark of a Jew's wandering, his having no country of his own to live in, and his having therefore set up home, ironically, in his own intelligence" (2004). Jacobson believes that humour is still a valuable talisman for Jewish people: "In an age of perilous certainties, we can't have too much wit or contradiction. I see the dangers inherent in endlessly rehearsing failures and casualties, but the 'permanent witticism' in which they are enshrined is a strategy for remembrance more than it is anything else, both an ironic saga of achievement and a methodology for survival" (2004). 


\section{Conclusion}

Patricia Waugh has argued that metafiction plays with the form of the novel and examines the old rules "in order to discover new possibilities of the game" (1993: 42). In Kalooki Nights Jacobson with his characteristic metatextual humour undermines the literary conventions that shape comic discourse, showing that comedy is as serious as tragedy and therefore capable of dealing with the more profound themes without trivializing them. Jacobson draws attention to the fact that comedy can treat the Holocaust respectfully while at the same time offering a different perspective. By self-consciously reflecting on the nature of comedy Jacobson not only vindicates its subversive character, but reaffirms his unconditional faith in the redeeming power of laughter, which he believes derives from his sense of Jewishness. Max tells his friend Errol Tobias that he has not read Did Six Million Really Die?, which questions the Holocaust, because "I can tell there are no laughs in it" (Jacobson 2007: 345). By doing so Max is not only celebrating comedy, but validating Jacobson's thesis that the ingenious, joking Jew is the Jew in essence.

\section{Notes}

1. Nathan Ausubel (1967) was the first to use the expression "laughter through tears" to describe the mixture of comedy and tragedy we find in Jewish humour.

2. The idea that Jewish humour is self-derogatory was originated by Freud in an aside on the nature of Jewish jokes in Jokes and Their Relation to the Unconscious: "A particularly favourable occasion for tendentious jokes is presented when the intended rebellious criticism is directed against the subject himself, or, to put it more cautiously, against someone in whom the subject has a share- a collective person, that is (the subject's own nation, for instance). The occurrence of self-criticism as a determinant may explain how it is that a number of the most apt jokes [...] have grown up on the soil of Jewish popular life. They are stories created by Jews and directed against Jewish characteristics [...]. Incidentally, I do not know whether there are many other instances of a people making fun to such a degree of its own character" (1966: 156-157). Freud made this causal remark in the context of a general discussion concerning the nature of tendentious jokes. He believed that tendentious jokes fulfilled a liberating function since they allowed people to criticize individuals or institutions to whom they were hostile or by whom they were oppressed.

${ }^{3}$. Ziv has argued that the reason why Jewish cartoonists were latecomers to the humour scene may have been because painting or drawing human images is prohibited by Jewish tradition (1988: 121).

${ }^{4}$. As Langer has explained, although it is hard to believe that nowadays Steiner would not modify some of the ideas he explored in Language and Silence, it is undeniable that he contributed to bringing to light many of the dilemmas faced by the writers concerned with the Holocaust: "His conceptions are fruitful as formulations of the tensions that afflicted the artist despite the fact that they led Steiner himself to negative judgments on the possibility of an art of atrocity" (1975: 15). 
5. Gilman disagrees with Des Pres. $\mathrm{He}$ believes that none of the comic representations of the Shoah are intended to evoke laughter: "It is clear, in spite of Des Pres's title, that no one ever actually laughed while reading Maus" (2000: 282). He affirms that only in the cinema has the comic seemed appropriate to deal with the Shoah.

${ }^{6}$. The notion that there is a distinctive Jewish mind has been endorsed by other Jewish authors. Thus, for instance, Cynthia Ozick believes that what Jews have in common is not so much language as the content of a civilization. No matter what language the Jewish writers use, Jewish culture is mainly a metaphysical culture: "Jews have many languages but one mind. Or, to put it yet another way: it is possible for Jews to have two 'homes' one linguistic and the other metaphysical" (Stavans et al. 1999: 49).

7. Jacobson is absolutely right in his evaluation of the effect of the Six-Day war and the Entebbe Raid on Israeli people. As Ziv has explained, the euphoria generated by the great military victory reinforced Israeli selfconfidence, which did not encourage the creation of humour (1988: 127-128).

\section{Works Cited}

AdLER, Hermann. 1893. "Jewish Wit and Humour". The Nineteenth Century 33: 457469.

Adorno, Theodor W. 1955. "Cultural Criticism and Society". In Prisms. Cambridge: MIT Press: 17-34.

Alter, Robert. 1987. "Jewish Humor and the Domestication of Myth". In Cohen, Sarah Blacher (ed.) Jewish Wry. Essays on Jewish Humor. Bloomington: Indiana U.P.: 25-36.

Ausubel, Nathan. 1967. A Treasury of Jewish Humor. New York: Paperback.

Berger, Peter L. 1997. Redeeming Laughter: The Comic Dimension of Human Experience. Berlin: Gruyter.

Boylan, Roger. 2011. "Seriously Funny". Boston Review (May/June). <http:// bostonreview.net/archives/BR36.3/roger_ boylan_howard_jacobson.php $>$. Accessed October 10, 2109.

Cheyette, Bryan. 1999. "Return of the Native". The Independent (August 21). <http://www. independent.co.uk/arts-entertainment/returnof-the-native-1114001.html?>.

Accessed January 18, 2014.

Cheyette, Bryan. 2003. “British-Jewish Literature". In Kerbel, Sorrel (ed.) Jewish Writers of the Twentieth Century. New York: Fitzroy Dearborn: 7-10.
COHEN, Sarah Blacher. 1987. “Introduction. The Varieties of Jewish Humor". In Cohen, Sarah Blacher (ed.) Jewish Wry. Essays on Jewish Humor. Bloomington: Indiana U.P.: 1-15.

Cory, Mark. 1995. "Comedic Distance in Holocaust Literature". Journal of American Culture 18 (3): 35-40.

DAVIES, Christie. 1991. "Exploring the Thesis of the Self-Deprecating Jewish Sense of Humor". Humor 4 (2): 189-209.

DES PRES, Terrence. 1991. "Holocaust Laughter?" In Writing into the World. Essays 1973-1987. New York: Viking Adult: 216-233.

FREUD, Sigmund. 1966. Jokes and their Relation to the Unconscious. London: Penguin.

Gilbert, Ruth. 2008. "Contemporary BritishJewish Writing: From Apology to Attitude". Literature Compass 5 (2): 394-406.

GILBERT, Ruth. 2013. Writing Jewish: Contemporary British-Jewish Literature. Basingstoke: Palgrave Macmillan.

GILMAN, Sander L. 2000. "Is life Beautiful? Can the Shoah be Funny? Some Thoughts on Recent and Older Films". Critical Inquiry 26 (2): $279-308$.

HASkIns, Casey. 2001. "Art, Morality, and the Holocaust: The Aesthetic Riddle of Benigni's 
Life Is Beautiful". The Journal of Aesthetics and Art Criticism 59 (4): 373-384.

Herschthal, Eric. 2010. "Can Howard Jacobson play in America?" The Jewish Week (August 31). <https://jewishweek.timesofisrael.com/ can-howard-jacobson-play-in-america/>. Accessed October 10, 2019.

HowE, Irving. 1988. "Writing and the Holocaust". In Lang, Berel (ed.) Writing and the Holocaust. New York: Holmes and Meier: 175-199.

IRVINE, Lindesay. 2010. "A Life in Writing: Howard Jacobson". The Guardian (August 7). $<$ http://www.theguardian.com/books/2010/ aug/07/howard-jacobson-life-writing/print>. Accessed January 18, 2014.

JACOBS, Gerald. 2008. "Interview: Howard Jacobson". The Jewish Chronicle Online (September 4). <https://www.thejc.com/ culture/interviews/interview-howardjacobson-1.4815>. Accessed October 10, 2019.

JacoBson, Howard. 2001. “Vay Iz Mir. Who'd Be a Jewish Writer?" The Jewish Quarterly 48 (1): 5-12.

JacoBson, Howard. 2004. "Being Jewish..." The Guardian (June 11). <http://www.the guardian.com/books/2004/jun/11/fiction. features11/print> Accessed May 2, 2015.

JACOBSON, Howard. 2006. "Now We Are 350". Jewish Quarterly 20: 41-46.

JACOBSON, Howard. (2006) 2007. Kalooki Nights. London: Vintage.

JACOBSON, Howard. 2010a. The Finkler Question. London: Bloomsbury.

JACOBSON, Howard. 2010b. "Howard Jacobson on Taking Comic Novels Seriously". The Guardian (Oct. 9). <https://www.theguardian. com/books/2010/oct/09/howard-jacobsoncomic-novels>. Accessed October 10, 2019.

JACOBSON, Howard. 2012. "In Praise of Bad Boys' Books". The Guardian (October 5). <http://www.theguardian.com/books/2012/ oct/05/howard-jacobson-bad-boys-books >. Accessed February 9, 2014.

Jeffries, Stuart. 2010. “Interview with Howard Jacobson". The Guardian (October 13). <https://www.theguardian.com/books/2010/ oct/13/howard-jacobson-booker-winnerinterview>. Accessed October 10, 2019.
KoHN, Jacob P. and Ludwig Davidsohn. 1943. "Jewish Wit and Humor". In Landman, Isaac (ed.) The Universal Jewish Encyclopedia 10. New York: Universal Jewish Encyclopedia: 545-547.

LANDMANN, Salcia. 1962. "On Jewish Humour". The Jewish Journal of Sociology 4 (2): 193203.

LANGER, Lawrence L. 1975. The Holocaust and the Literary Imagination. New Haven and London: Yale U.P.

MAnus, Elizabeth. 2004. "Interview with Howard Jacobson". Something Jewish (September 15). <https://www.tabletmag. com/jewish-arts-and-culture/books/781/janesheir>. Accessed October 10, 2019.

MuLlaN, John. 2010. "Howard Jacobson on Writing Kalooki Nights". The Guardian (October 2). <https://www.theguardian.com/ books/2010/oct/02/book-club-howardjacobson-kalooki>. Accessed February 1, 2013.

OrING, Elliott. 1983. "The People of the Joke: On the Conceptualization of a Jewish Humor". Western Folklore 42 (4): 261-271.

Pearson, Allison. 2003. "Howard Jacobson". Telegraph (April 27). <http://www.telegraph. co.uk/culture/books/3593433/HowardJacobson.html>. Accessed February 1, 2013.

"The Plot against England". 2010. Tablet (October 11). <http://www.tabletmag.com/ jewish-news-and-politics/46961/the-plotagainst-england>. Accessed March 21, 2012.

SAPER, Bernard. 1991. "A Cognitive Behavioral Formulation of the Relation between the Jewish Joke and anti-Semitism". Humor: International Journal of Humor Research 4 (1): 41-59.

Schischa, Rebecca. 2011. "British Jewish Culture Surging into the Mainstream". The Jewish Week (March 22). <https://jewishweek. timesofisrael.com/british-jewish-culturesurging-into-the-mainstream/>. Accessed October 10, 2019.

Sicher, Efraim and Linda Weinhouse. 2012. "Radically Jewish. Diaspora Jews, Diaspora Blues". In Under Post-Colonial Eye. Figuring the Jew in Contemporary British Writing. Nebraska: University Press of Nebraska: 199246.

Stavans, Ilan, Melvin Jules Bukiet and Cynthia Ozıck. 1999. "Authenticity and Marginality. A 
Discussion on Jewish Literature Today". The Jewish Quarterly 46 (3): 47-52.

SteineR, G. 1985. "K". In Language and Silence. Essays 1958-1966. London: Faber and Faber: 141-149.

TracY, Marc. 2011. "Humorous? Yes. Tragic? Definitely". Tablet (April 5). <http://www. tabletmag.com/scroll/63997/the-tragic-wittycontroversial-witty-raconteur>. Accessed March 18, 2012.

VIANo, Maurizio. 1999. "Life Is Beautiful. Reception, Allegory, and Holocaust Laughter". Film Quarterly 53 (1): 26-34.
WaUgh, Patricia. 1993. Metafiction. The Theory and Practice of Self-Conscious Fiction. London: Routledge.

WEBER, Donald. 2007. "Anglo-Jewish Literature Raises its Voice". JBooks (July 12). <http:// www.jbooks.com/interviews/index/IP_Weber_ English.htm>. Accessed February 3, 2014.

ZIV, Avner. 1986. "Psycho-Social Aspects of Jewish Humor in Israel and the Diaspora". In Ziv, Avner (ed.) Jewish Humor. Tel Aviv: Papyrus: 47-71.

ZIV, Avner. 1988. "Humor in Israel". In Ziv, Avner (ed.) National Styles of Humor. Westport: Greenwood Press: 113-131.

Received: $12 / 04 / 2018$

Accepted: $27 / 08 / 2018$ 